The Conformational Manifold of $\alpha$-Aminoisobutyric Acid (Aib) Containing Alanine-Based Tripeptides in Aqueous Solution Explored by Vibrational Spectroscopy, Electronic Circular Dichroism Spectroscopy, and Molecular Dynamics Simulations.

\author{
Reinhard Schweitzer-Stenner ${ }^{\dagger *}$, Widalys González, ${ }^{\dagger}$ Gregory T. \\ Bourne ${ }^{\ddagger}$, Jianwen A. Feng ${ }^{\ddagger}$, and Garland R. Marshal, ${ }^{\ddagger}$
}

\footnotetext{
${ }^{\dagger}$ Department of Chemistry, Drexel University, 3141 Chestnut Street, Philadelphia, Pennsylvania 19104 and Department of Biochemistry and Molecular Biophysics, Washington University, St. Louis, Missouri 63110
}

Supporting Information 


\section{Materials and Method.}

NMR Spectroscopy. Nuclear Magnetic Resonance spectra were recorded at $300 \mathrm{MHz}\left({ }^{1} \mathrm{H}\right) / 75$ $\mathrm{MHz}\left({ }^{13} \mathrm{C}\right)$ on a Varian Gemini-300 and NMR spectrometers. ${ }^{1} \mathrm{H}$ and ${ }^{13} \mathrm{C}$ chemical shifts $(\delta)$ are given in parts per million (ppm) using residual protonated solvent as an internal standard. Coupling constants are given in Hertz $(\mathrm{Hz})$. The following abbreviations are used: $\mathrm{s}=$ singlet, $\mathrm{d}=$ doublet, $\mathrm{t}=$ triplet, $\mathrm{m}=$ multiplet. Low resolution mass spectral data were recorded on $\mathrm{a}$ Micromass LCT (TOF MS ES+) instrument.

Melting points were determined on a Bausch and Lomb hot stage. Analytical reversed-phase HPLC was performed on a Phenenomex $\mathrm{C}_{18}$ Jupiter column $(4.6 \times 250 \mathrm{~mm})$. Preparative reversed phase HPLC was performed on a Phenonemex Gemini $\mathrm{C}_{18}$ column $(22$ x $250 \mathrm{~mm})$ Separations were achieved using linear gradients of buffer $\mathrm{B}$ in $\mathrm{A}(\mathrm{A}=$ aqueous $0.045 \% \mathrm{HCl} ; \mathrm{B}=90 \%$ $\mathrm{CH}_{3} \mathrm{CN}, 10 \% \mathrm{H}_{2} \mathrm{O}, 0.045 \%$ aqueous $\mathrm{HCl}$ ) at a flow rate of $1 \mathrm{~mL} / \mathrm{min}$ (analytical) and 15 $\mathrm{mL} / \mathrm{min}$ (preparative). Abbreviations: $\mathrm{MeCN}$, acetonitrile; $\mathrm{HCl}$, hydrogen chloride; $\mathrm{DCM}$, dichloromethane; petrol, petroleum spirit (bp $40-60{ }^{\circ} \mathrm{C}$ ); EtOAc, ethyl acetate; DIEA, diisopropylethyl amine; $\mathrm{AcOH}$, acetic acid; $\mathrm{MeOH}$, methanol; $\mathrm{Et}_{2} \mathrm{O}$, diethyl ether; $\mathrm{DMSO}$, dimethylsulfoxide; DMF, $N, N$-dimethylformamide; HBTU, O-benzotriazol-1-yl- $N, N, N^{\prime}, N^{\prime}-$ tetramethyluronium hexafluorophosphate; HATU, O-(7-azabenzotriazol-1-yl)- $N, N, N^{\prime}, N^{\prime}-$ tetramethyluronium hexafluorophosphate.

Synthesis of Ac-Aib-OH. H-Aib-OH (1.03 g, $10 \mathrm{mmol})$ was dissolved with stirring in boiling acetic acid to give a $10 \% \mathrm{w} / \mathrm{v}$ solution. After allowing the solution to cool slightly, acetic anhydride (1.53 g, $15 \mathrm{mmol}, 1.5$ equiv.) was added in portions over a 10minute period. The mixture was refluxed for 5-10 min, allowed to cool overnight, and the solvent evaporated to give a syrup, to which water $(50 \mathrm{~mL})$ was added and the solution 
was re-evaporated. This process was repeated until a solid was obtained. The solid was washed with ice-water, then dried under vacuum. The solid, free from acetic acid was recrystallized from $\mathrm{H}_{2} \mathrm{O}$ to give the desired product. (0.25 g, $40 \%$ ). ${ }^{1} \mathrm{H}$ NMR (300 MHz, $\mathrm{d}^{6}$-DMSO) $\delta 1.22\left(\mathrm{~s}, 6 \mathrm{H}, \mathrm{C}\left(\mathrm{CH}_{3}\right)_{2}\right), 1.68\left(\mathrm{~s}, 3 \mathrm{H}, \mathrm{CH}_{3} \mathrm{CO}\right), 7.92(\mathrm{~s}, \mathrm{NH}) 11.98(\mathrm{br} \mathrm{s}, 1 \mathrm{H}$, $\mathrm{OH}) ;{ }^{13} \mathrm{C}$ NMR (75 MHz, d $\mathrm{d}^{6}$-DMSO) $\delta$ 23.1, 25.6, 55.2, 169.2, 176.2. ES-MS Mr 145.2, calcd for $\mathrm{C}_{6} \mathrm{H}_{11} \mathrm{NO}_{3}, 145.1$ (monoisotopic). ${ }^{1}$

Synthesis of linear peptides. All linear peptides were chemically synthesised on chlorotrityl resin stepwise using Fmoc protecting groups and in situ HBTU activation protocols as previously described. ${ }^{2,3}$ Coupling efficiencies were determined by the quantitative ninhydrin test ${ }^{4}$ and recoupled where necessary to obtain $>99.5 \%$ efficiency. The linear peptides were cleaved from resin using 95\% TFA with $5 \% \mathrm{H}_{2} \mathrm{O}$. The product was purified by reverse-phase HPLC. No TFA was used in the preparative HPLC. The procedure yielded the following results. Ac-Ala-Ala-Aib-OH: Yield after cleavage and purification was $142 \mathrm{mg}$ (71\%); ES-MS $\mathrm{Mr}$ 287.2, calculated for $\mathrm{C}_{12} \mathrm{H}_{21} \mathrm{~N}_{3} \mathrm{O}_{5}, 287.2$ (monoisotopic); Ac-Ala-Aib-Ala-OH: Yield after cleavage and purification was $156 \mathrm{mg}$ (78\%); ES-MS Mr 287.3, calculated for $\mathrm{C}_{12} \mathrm{H}_{21} \mathrm{~N}_{3} \mathrm{O}_{5}, 287.2$ (monoisotopic); Ac-Aib-AlaAla-OH: Yield after cleavage and purification was $171 \mathrm{mg}$ (86\%); ES-MS Mr 287.3, calculated for $\mathrm{C}_{12} \mathrm{H}_{21} \mathrm{~N}_{3} \mathrm{O}_{5}, 287.2$ (monoisotopic).

General method for methyl ester formation. The linear peptides were dissolved in $2 \mathrm{~mL}$ EtOH and diazomethane in ether $(20 \mathrm{~mL}$ of $0.4 \mathrm{M}$ solution) was added dropwise at room temperature. The solution was left standing for 60 minutes, $1 \mathrm{~mL}$ of HOAc added to 
neutralize the excess diazomethane and solvents removed under vacuum. The residue was taken up in $3 \mathrm{~mL}$ aqueous acetonitrile (50\%) and lyophilized. Preparative HPLC gave the desired products. No TFA was used in the preparative HPLC. The procedure yielded the following results. Ac-Ala-Ala-Aib- $\mathrm{OCH}_{3}$ : Yield after cleavage and purification was 103 mg (80\%); ES-MS $M r$ 301.2, calcd for $\mathrm{C}_{13} \mathrm{H}_{23} \mathrm{~N}_{3} \mathrm{O}_{5}, 301.2$ (monoisotopic); Ac-Ala-AibAla- $\mathrm{OCH}_{3}$ : Yield after cleavage and purification was $122 \mathrm{mg}$ (87\%); ES-MS Mr 301.3, calculated for $\mathrm{C}_{13} \mathrm{H}_{23} \mathrm{~N}_{3} \mathrm{O}_{5}, 301.2$ (monoisotopic); Ac-Aib-Ala-Ala-OCH $\mathrm{OCH}_{3}$ : Yield after cleavage and purification was $147 \mathrm{mg}$ (91\%); ES-MS Mr 301.3, calculated for $\mathrm{C}_{13} \mathrm{H}_{23} \mathrm{~N}_{3} \mathrm{O}_{5}, 301.2$ (monoisotopic). 


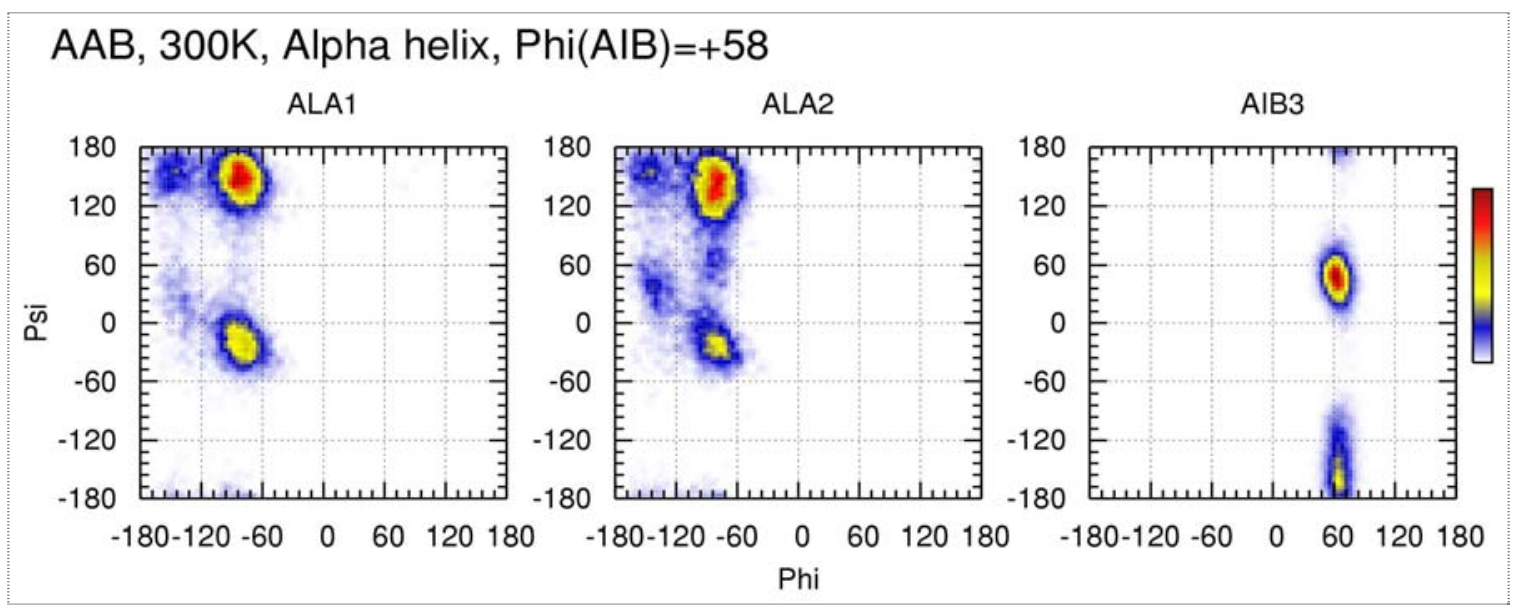

AAB, 300K, Beta strand, Phi(AIB $)=+58$

ALA1

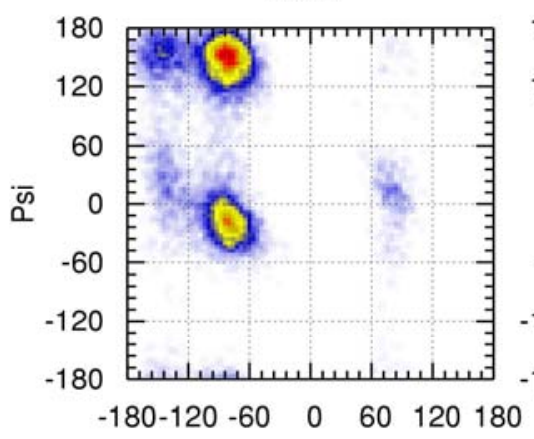

ALA2

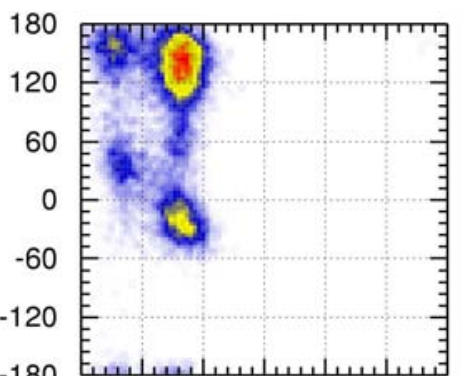

-180-120-60 $0 \quad 60 \quad 120180$ Phi

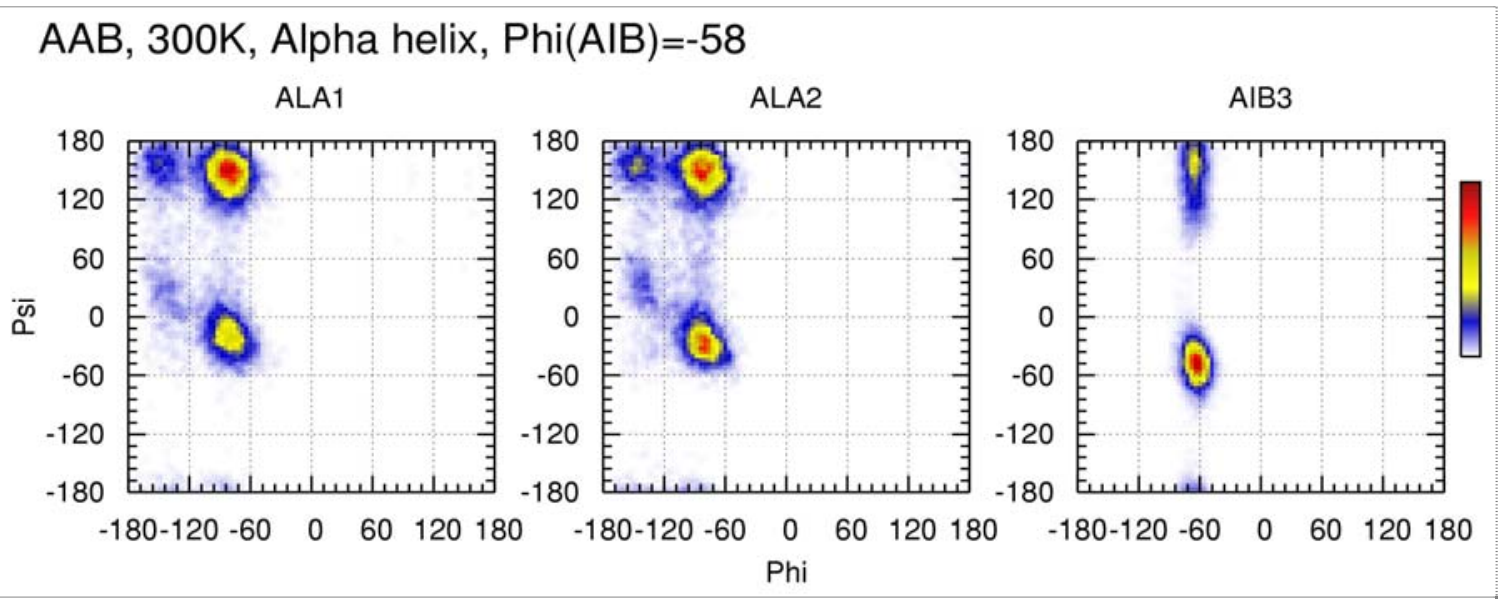




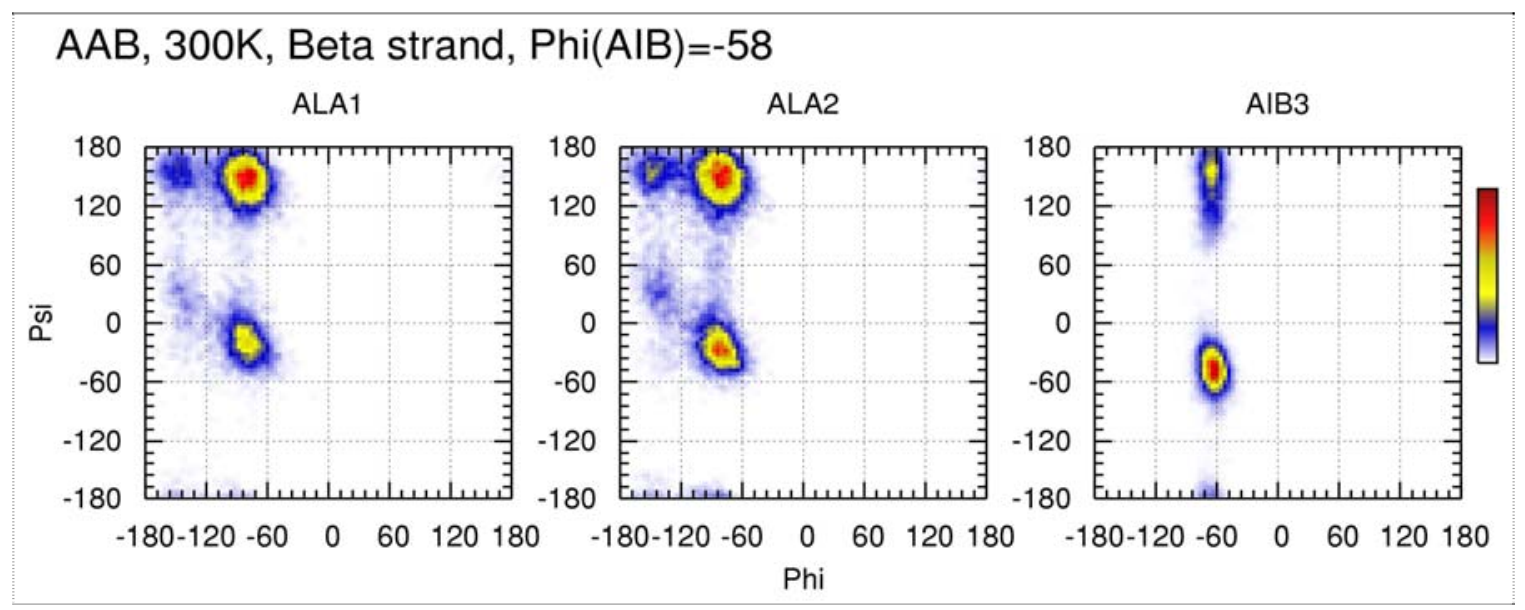

Figure S1: Summary Ramachandran plots of four Ac-AlaAlaAib-OMe (AAB) simulations at $300^{\circ} \mathrm{K}$. 

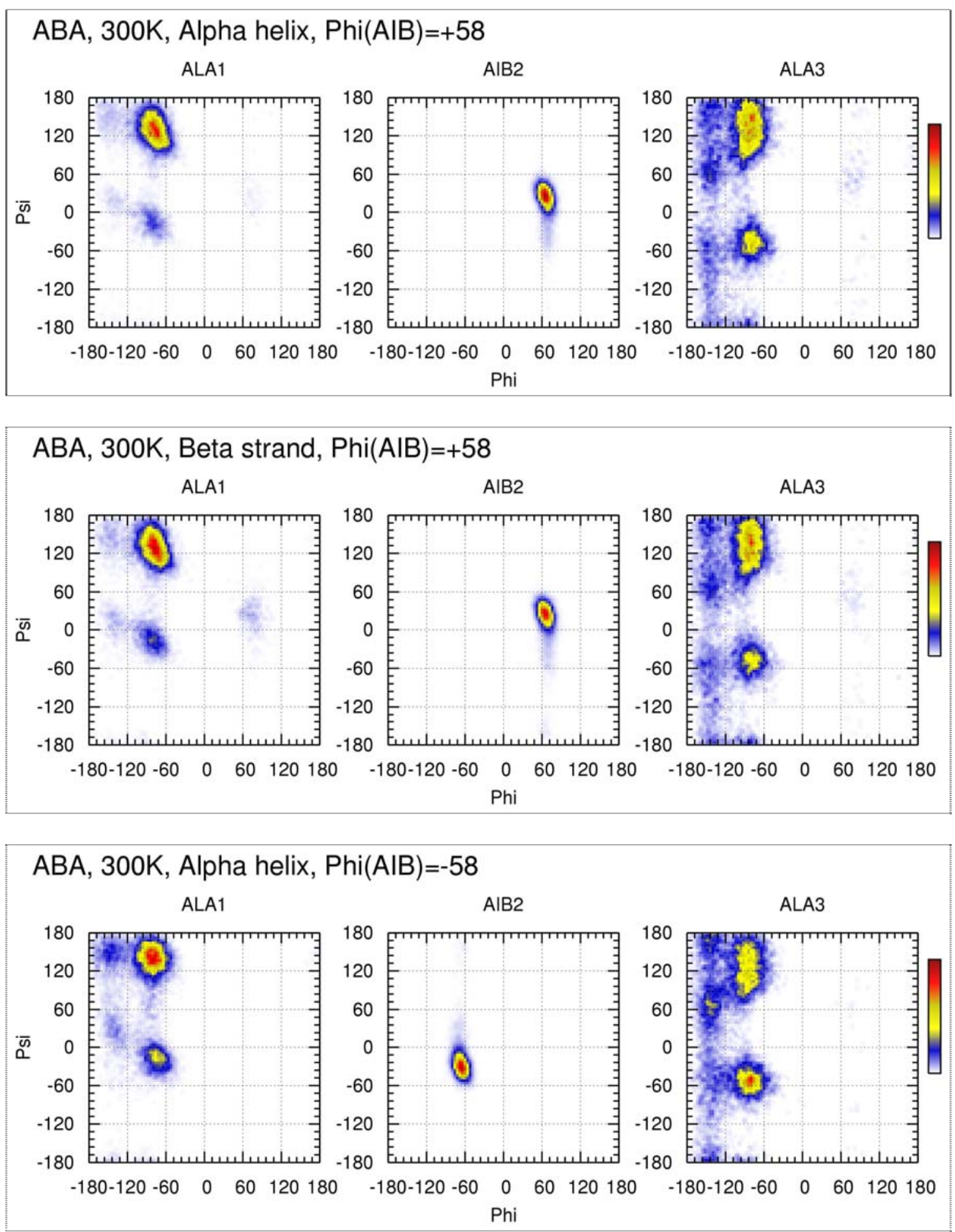


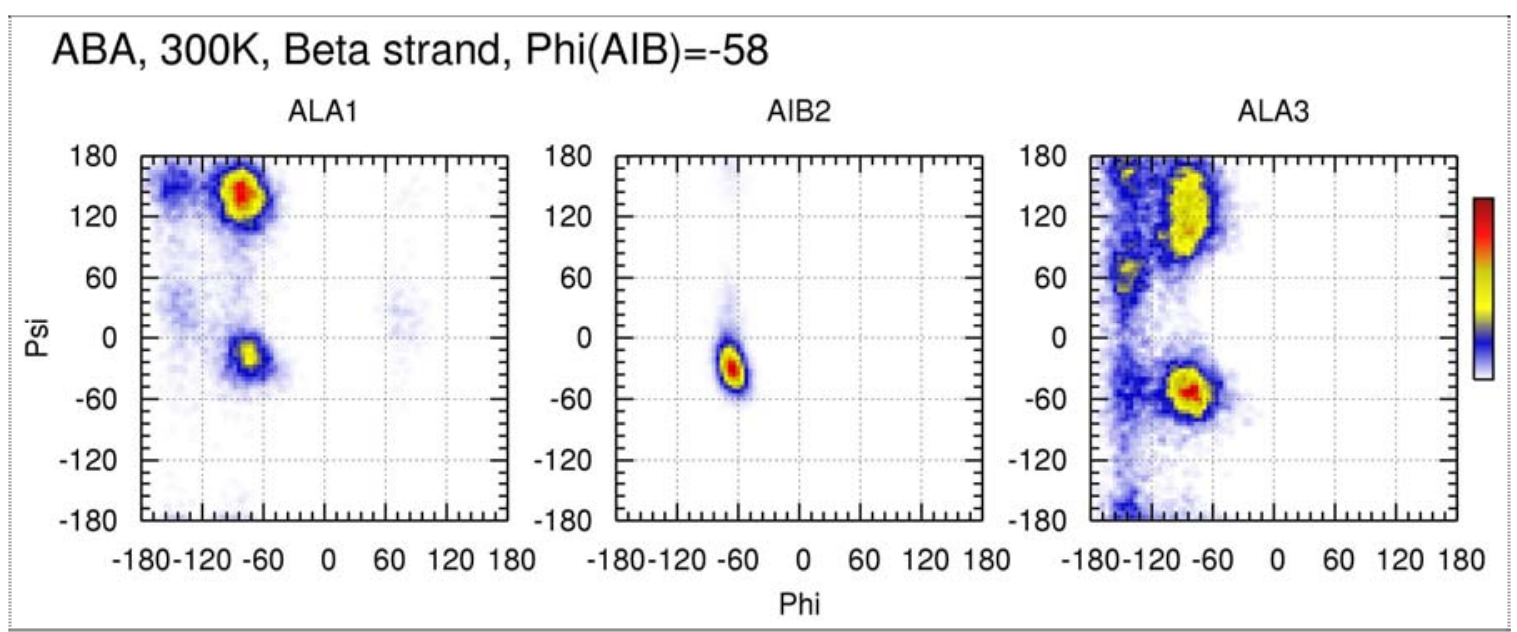

Figure I2: Summary Ramachandran plots of four Ac-AlaAibAla-OMe (ABA) simulations at $300^{\circ} \mathrm{K}$. 


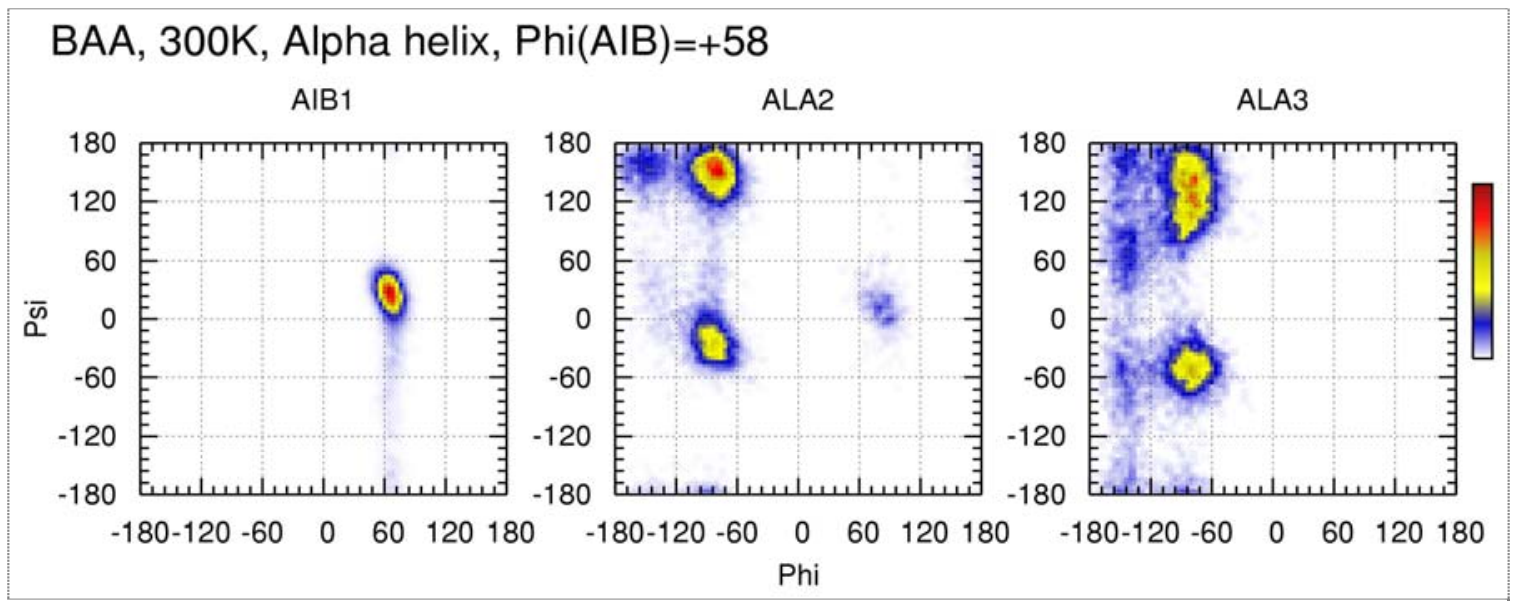

BAA, 300K, Beta strand, Phi(AIB $)=+58$

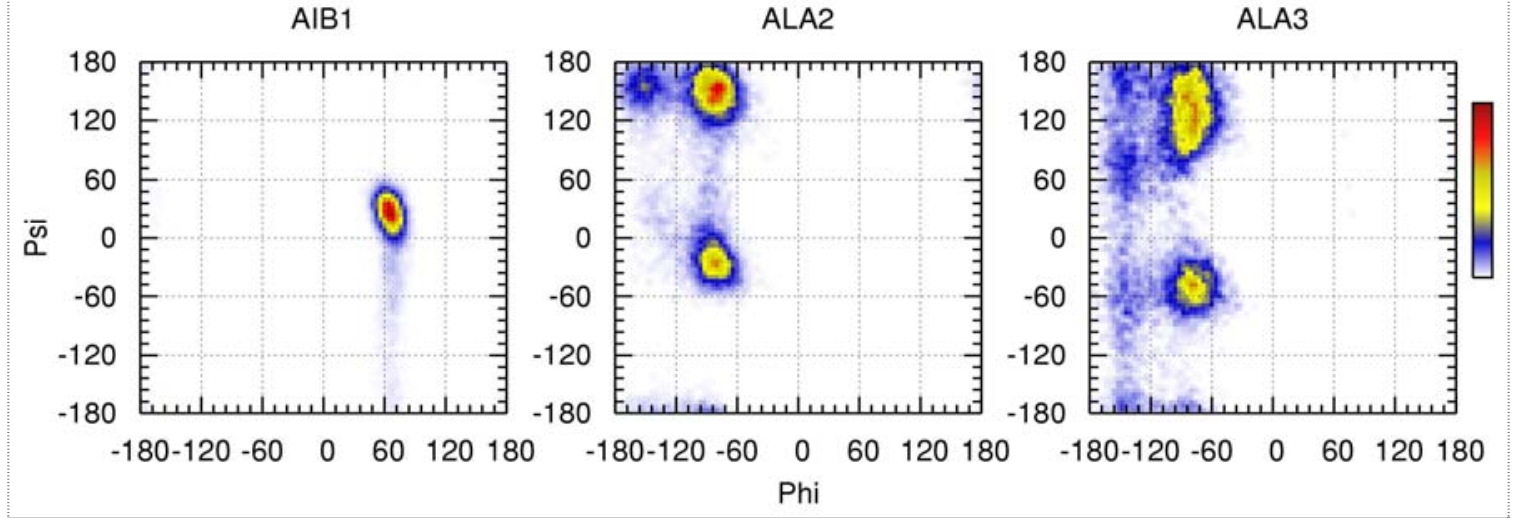

BAA, 300K, Alpha helix, Phi(AIB) $=-58$

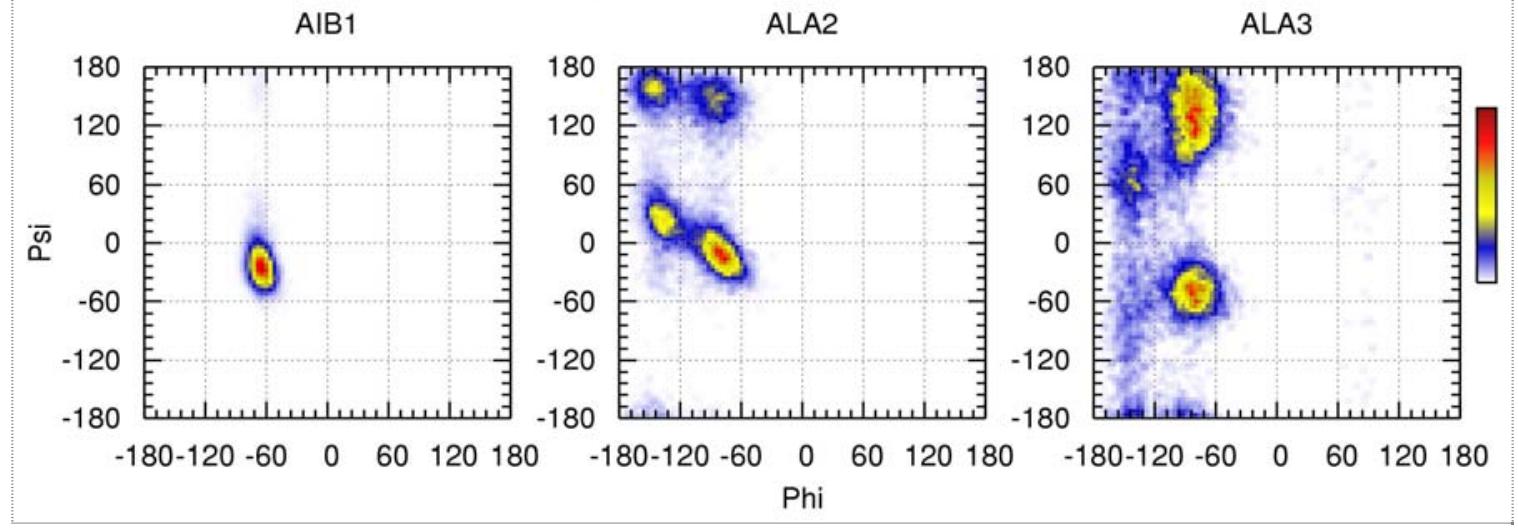




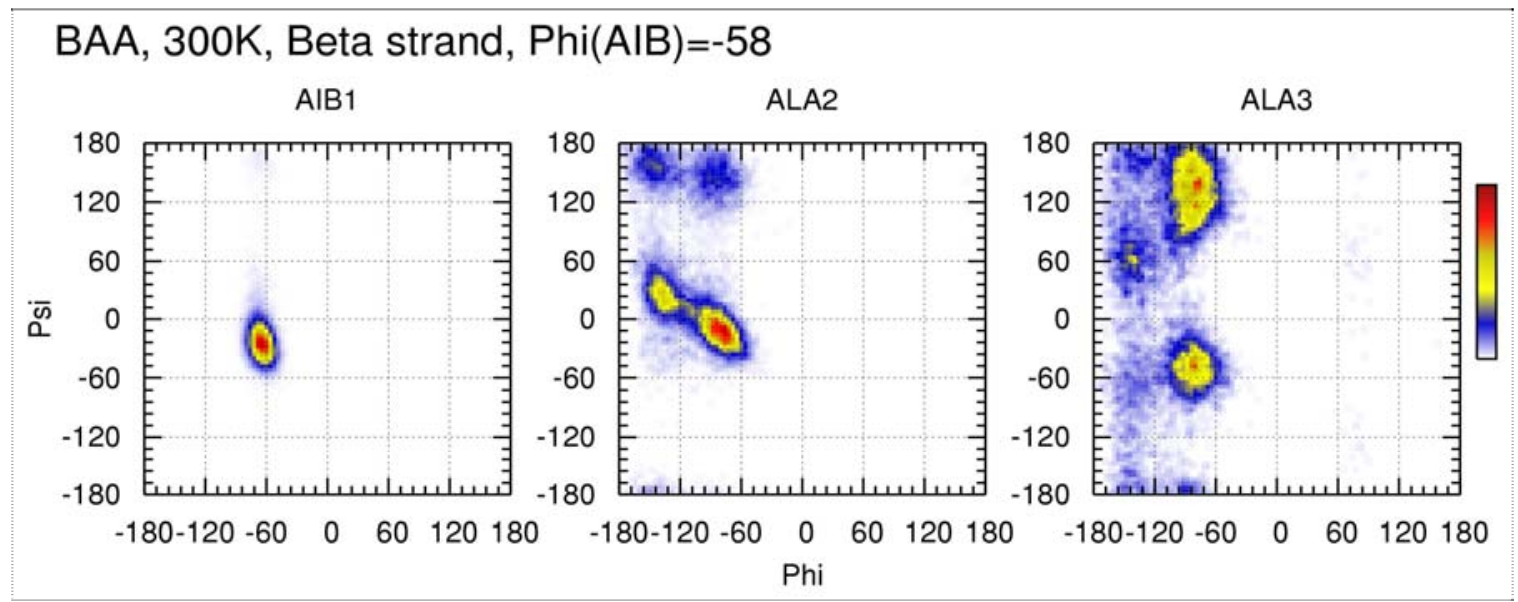

Figure 13: Summary Ramachandran plots of four Ac-AibAlaAla-OMe (BAA) simulations at $300^{\circ} \mathrm{K}$. 


\section{References}

1. Cotton, R., Hardy, P. M.; Langran-Goldsmith, A. E., Int. J. Peptide Protein Res., 1986, 28, 230-244.

2. Schnölzer, M.; Alewood, P. F.; Jones, A.; Alewood, D.; Kent, S. B. H.; Int. J. Pept. Protein Res., 1992, 40, 180-93.

3. Alewood, P.; Alewood, D.; Miranda, L.; Love, S.; Meutermans W.; Wilson, D. Methods Enzymol., 1997, 289, 14-29.

4. Sarin, V. K.; Kent, S. B. H.; Tam J. P.; Merrifield R. B.; Anal. Biochem., 1981, 117, 147-157. 